\title{
Össznyelvész Konferencia 2020
}

\section{(ELTE BTK Nyelvelméleti Kutatóközpont, online konferencia, 2020. december 22.)}

\author{
Cseh Lilla Zsófia \\ E-mail:l.zsofia.cseh@gmail.com
}

Az Össznyelvész Konferenciát 2020. december 22-én negyedik alkalommal rendezte meg az ELTE Nyelvelméleti Kutatóközpont (NYEKK). Célja ezúttal is az volt, hogy népszerüsítse az elméleti és alkalmazott nyelvészeti ágakat, alkalmat adjon a tudományterület müvelőinek, hogy nagyobb közönség előtt mutassák be kutatási témájukat.

Az első Össznyelvész Konferenciát a NYEKK és az ELTE BTK Hallgatói Önkormányzata (ELTE BTK HÖK) szervezte 2017. november 10-én az ELTE BTK Angol-Amerikai Intézetének épületében. A 2018-as konferenciát december 7-én tartották ugyanott, a 2019-es konferenciát elhalasztották, végül 2020. január 2425-én tartották meg az említett helyszínen.

2020-ban a COVID-19 járványhelyzet miatt nem lehetett a konferenciát jelenléti jellegüen megszervezni, emiatt 2020. december 22-én, egy erre a célra kialakított Discord-szerveren lehetett csatlakozni, megnézni-hallgatni az előadásokat. A konferencia 2017-ben csak egy szekcióban zajlott, 2018-tól már kettőben, de minden évben volt alkalom, amikor egy adott idöpontban - jellemzöen a konferencia végén - csak egy előadás hangzott el. Plenáris előadások egyik évben sem voltak.

A Konferencia 2020-ban két szekciót foglalt magába: Elméleti és Kognitív Nyelvészet (Theoretical Linguistics \& Cognitive Linguistics) 12 előadással és Alkalmazott Nyelvészet és Nyelvpedagógia (Applied Linguistics \& Language Pedagogy) 11 előadással. Az előadások témája bármi lehetett, ami az említett területekhez kapcsolódik; az online forma és korlátozott időkeret miatt az előadások témájuk szerint nem különültek élesen el a két szekcióban.

A számos külföldi résztvevő és a néhány külföldi előadó miatt az előadások a magyaron kívül angol nyelven is elhangozhattak. A 23 elöadásból 10 volt angol nyelvü.

A Discord adatai szerint a konferencián körülbelül százan vettek részt, a legtöbb előadás során a két szekcióban nagyjából azonos volt a részvételi arány. Kivételt képzett az a négy alkalom, amikor az egyik előadás angol nyelven, a másik

Hivatkozás: Cseh L. Zs. 2021. Össznyelvész konferencia. (ELTE BTK Nyelvelméleti Kutatóközpont, online konferencia, 2020. december 22.) Forditástudomány 23. évf. 1. szám. 105-106. DOI: https://doi.org/10.35924/fordtud.23.1.7 
magyar nyelven zajlott, amikor a külföldi résztvevők döntő többsége az angol nyelvüt választotta; illetve a konferencia harmadik, 14:10-től 15:40-ig tartó része, amikor mindkét szekcióban kizárólag magyar nyelvü előadások hangzottak el. Minden előadás legfeljebb 20 perces lehetett (az időkeretet mindenki be is tartotta), ugyanakkor 15 percnél nem rövidebb. Így mindegyik után maradt 10 perc kérdésekre, a téma megvitatására.

A második, alkalmazott nyelvészeti szekcióban az előadások nagy része tágabb témákat dolgozott fel; az elsőben több volt a konkrét nyelvekre, és azok egyéni sajátosságaira koncentráló anyag. Nagy örömömre én is lehetőséget kaptam elöadásra, az első szekcióban. Doktori témám: Cultural differences and translation issues in translating manga and subtitling anime. Mivel a doktorit angol nyelven tervezem írni, angol nyelven is adtam elö: Japanese customs as presented in manga and anime, and related translation questions. Azt a kérdést jártam körül, hogy a japán mindennapi élet részletei és a szokások hogyan jelennek meg a manga és anime (japán képregény és animáció) világában, hogyan lehetséges ezeket a finom részleteket e különleges médiumokban lefordítani, megmagyarázni, vagy lehet-e kulturális átültetést alkalmazni. Érdekes példákat is bemutattam, és összehasonlítottam olasz, illetve angol fordítási megoldásokat.

A konferencia számomra két legérdekesebb előadása a második szekcióban hangzott el: A II. Rákóczi Ferenc Kárpátaljai Magyar Főiskola hallgatója, Kiss Krisztina Digitális kompetenciák: az információszürés kérdései és az álhírekhez való viszonyulás a kárpátaljai magyarok körében címmel egy nagyon izgalmas, sok képet és kuriózumokat felvonultató bemutatója nagyon jól volt felépítve. Tágabb értelemben kezdte az álhírekkel, utána beszélt a kárpátaljai magyarok hozzáféréséről az információ-adatbázisokhoz, és végül a kettőt keresztezve foglalta össze a témát. A másik Ibtissem Smari, a Pannon Egyetem PhD-hallgatója The multilingual identity: Tunisian case study címü előadása volt. A többnyelvüséget mindig is fontos témának tartottam, és Ibtissem Smari a Tunéziában második főbb nyelvként használatos francia nyelv fejlődését követte nyomon az ország 1956-os függetlenedése előtt és föleg azóta, bemutatva, hogy az arab nyelv hatása miatt mennyi változata alakult ki a különbözö földrajzi területeken.

A konferencia, mivel lehetőséget adott számos jelenleg is kutatásokat végző diáknak a témája bemutatására, nagyon érdekes volt: betekintést nyerhettünk az aktuális témák, jelenleg fontos kérdéskörök helyzetébe a tanulmányok terén.

A rendezés az online forma miatt (a Discord kevésbé ismert, mint a Zoom felülete) néhány nappal december 22. előtt próbával kezdődött. Ekkor mindenki kipróbálhatta, le tudja-e PPT bemutatóját vetíteni, és a hanggal sincsen-e probléma. A konferencia maga zökkenőmentesen zajlott, de sajnos egy-két előadás során a hangminőség nem volt a legjobb. Szerencsére a kérdezz-felelek részeknél ez orvosolható volt: a kérdező és az előadó tudott írásban is kommunikálni.

2021-es konferenciáról eddig még nem érkeztek hírek. Információért az ossznyelvesz@gmail.com címre lehet írni, fö kontakt személy Garai Luca, jelenleg tanársegéd az ELTE BTK Angol-Amerikai Intézetében. 